BRIEF REPORT

\title{
Changes of knowledge, attitudes, beliefs, and preference of bar owner and staff in response to a smoke-free bar law
}

\author{
H Tang, D W Cowling, C M Stevens, J C Lloyd
}

See end of article for authors' affiliations

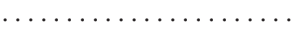

Correspondence to: Hao Tang, PO Box 942732, MS 7209

Sacramento 94234-7320,

USA; htang@dhs.ca.gov

Received 29 April 2003

Accepted 19 August 2003

\begin{abstract}
Objective: To examine attitudinal changes of bar owners and staff regarding a smoke-free bar law. Design: Bar owners and staff were random selected and telephone interviewed in June 1998, shortly after a smoke-free bar law was enacted, and October 2002. Similar instruments were used in both surveys to collect data on attitudes related to secondhand smoke (SHS) and behaviours related to the smoke-free bar law.

Participants: 651 and 650 respondents worked for either stand alone bars or combination bars. Measures: Preference of working in a smoke-free environment, concerns of the effect of SHS, and how to comply with the law.

Results: The percentage of bar owners or staff working in stand alone bars who prefer to work in a smokefree environment increased from 17.3\% in 1998 to $50.9 \%$ in 2002 ( $p<0.001$ ). Significantly more respondents $(45.5 \%)$ working in stand alone bars were concerned about the effects of SHS on their health, comparing to $21.6 \%$ in 1998 ( $p<0.001$ ). When patrons smoked in the bar, $82.1 \%$ of stand alone bar owners or staff in the 2002 survey would ask them to stop or to smoke outside, increased from only $43.0 \%$ in the 1998 survey $(p<0.001)$.

Conclusion: A positive and significant attitudinal change related to the smoke-free bar law occurred among California bars.
\end{abstract}

$\mathrm{S}$ econdhand smoke (SHS) is a major public health concern, especially for hospitality workers, who have high exposure from their working environment. ${ }^{12}$ Environmental evidence has shown that bar and tavern workers have higher exposure to SHS in comparison to workers in general, ${ }^{3}$ and biological research has indicated that bar employees working in places without a smoking ban have higher hair nicotine levels than their peers working in a smoke-free environment. ${ }^{45}$ Furthermore, Eisner et al reported that bartenders' respiratory health improved after smoking was banned in their workplace. ${ }^{6}$ Those findings suggest that prohibition of smoking in bar establishments is an effective policy to protect bar workers as well as patrons from involuntary exposure to SHS.

Despite the mounting evidence, only two states and 95 municipalities in the USA have adopted ordinances to completely ban smoking in bar establishments as of 3 June 2003. ${ }^{7}$ California became the first state banning smoking in all indoor bars, when a provision of the State's 1994 Assembly Bill 13 went into effect in January 1998. ${ }^{8}$ Opposition from the tobacco industry, the National Smokers Alliance, and some bar owners was strong before and after enactment of the law, by complaining that bars would lose patronisation, resulting in revenue decline. ${ }^{9-11}$ In contrast to these claims, studies not only indicated that bar patrons strongly supported the law, were more likely to visit bars, and actually stayed longer, ${ }^{12}$ but also showed that the law had no negative impact on bar revenues. ${ }^{13-15}$

In order to promote and facilitate implementing this smoke-free bar law, many health promotion approaches, including a statewide smoke-free bar project (BREATH), a focused media campaign, a coordinated and sustained community level campaign, and enforcement activities sponsored by California Tobacco Control Program, have been employed. ${ }^{16-18}$

Previous studies have shown public opinion changes after public health laws, including seat belt use, drunk driving, and smoke-free dining, took effect. ${ }^{12}{ }^{19-21}$ Besides California, only Delaware has implemented a workplace smoking ban in November 2002 that encompasses bars in November 2002; four more states (New York, Connecticut, Maine, and Florida) are in the process of implementing similar ordinances. While more and more state and local governments are pursuing this kind of comprehensive SHS workplace protection policy, little is known of the public acceptance of the law, especially among key stakeholders such as bar owners and employees.

To our knowledge, our study is the first effort to examine changes of knowledge, attitudes, beliefs, and preference of bar owners and staff after a smoke-free bar law was introduced. Such information will be helpful for other states as well as local governments considering this important public health policy.

\section{METHODS}

In June 1998 and October 2002, a total sample of 651 and 650 respondents working for bars were telephone interviewed by Field Research Corporation (San Francisco, California) at their place of work, either in English or Spanish. Stand alone bars and combination bars (that is, those connected to restaurants, hotels or card clubs) were randomly selected from the licence list provided by California Department of Alcohol and Beverage Control (approximate 37000 entries) except that stand alone bars were intentionally over-sampled $(\mathrm{n}=393)$ in 1998 in order to better understand the attitudes of their owners and employees, who were perceived to be less likely to welcome the new law. The number of stand alone bars randomly selected and surveyed in 2002 was 112. Cooperation rate was $80.0 \%(651 / 814)$ in 1998 and $72.0 \%$ $(650 / 903)$ in 2002 survey. Because the licence list used in 2002 was eight months old, there was a larger proportion of sample that was not reachable in 2002 compared to the 1998 survey, which employed a more updated licence list. As a 
result, the overall response rate was $47.4 \%(651 / 1372)$ in 1998 and $31.9 \%(650 / 2036)$ in the 2002 survey.

For each bar, only one interview was conducted. When a bar was contacted, the interviewer first asked to speak to the owner of the establishment, the proprietor or general manager. If that person was not available, the interviewer asked to speak to the bar manager or assistant manager, and to the bartender if the manager was not available. In 1998, $38 \%$ of respondents were owners or general managers; $28 \%$ were bar managers or assistant managers; and 34\% were bartenders. The proportions were similar in 2002 (37\%, 31\%, and $31 \%$, respectively).

Similar instruments were used in both surveys to collect data on knowledge, attitudes, beliefs, and preferences related to SHS and the smoke-free bar law (table 1). Data were weighted based on the licence list. We examined unweighted data of stand alone bars and combination bars separately to assess changes over time. $\chi^{2}$ tests were conducted using SAS V8.2. PROC FREQ. ${ }^{22}$

\section{RESULTS}

The percentage of bar owners or staff working in stand alone bars who prefer to work in a smoke-free environment almost tripled from $17.3 \%$ in 1998 to $50.9 \%$ in 2002 ( $p<0.001$ ). At the same time, nearly $80 \%$ of respondents working in a combination bar preferred a smoke-free environment in the 2002 survey, up from 52.3\% in 1998. In 2002, significantly more respondents $(45.5 \%)$ working in stand alone bars were concerned about the effects of SHS on their health, increasing from $21.6 \%$ in $1998(\mathrm{p}<0.001)$. Similarly, $57.1 \%$ of stand alone bar owners and staff in the 2002 survey said having a smoke-free environment inside their bars was important, compared to only $20.9 \%$ in 1998 ( $p<0.001$ ). The percentage of combination bar respondents who consider having a smoke-free environment as important was $58.1 \%$ in 1998 which increased to $80.5 \%$ in 2002 ( $p<0.001)$.

When given a hypothetical scenario regarding how they would respond to a patron smoking in their bar, $82.1 \%$ of stand alone bar owners or staff in the 2002 survey said they would ask the patron to stop or to smoke outside. Only $43 \%$ of stand alone bar respondents would do so in the 1998 survey $(p<0.001)$. The percentage of respondents who would tell patrons "it's against the law" decreased significantly, from $62.9 \%$ in 1998 to $33.0 \%$ in 2002 ( $p<0.001$ ). These two answer options were included in a single question and multiple choices were allowed.

In 2002, $88.0 \%$ of the combination bar respondents and $53.6 \%$ stand alone bar respondents considered complying with the law as easy. A majority of the combination bar respondents $(86.8 \%)$ and stand alone bar respondents $(65.2 \%)$ agreed with the statement that the smoke-free bar law protected their health and the health of other bar employees.

Logistic regression analyses on weighted data showed that after controlling for type of bar, respondent's position in the bar, and smoking status, the odds ratios for preferring working in smoke-free bar, concerns about SHS, and the importance of the smoke-free environment were 3.78 (95\% CI 2.89 to 4.94$), 1.31$ (95\% CI 1.04 to 1.65$)$, and 3.05 (95\% CI 2.35 to 3.94 ), respectively (data not shown).

\section{DISCUSSION}

This study showed that a positive and significant attitudinal change occurred among California's bar owners, managers, and bartenders regarding SHS and the smoke-free bar law in a four and a half year span. Although the law was well received among general public, ${ }^{13}$ the survey conducted months after the enactment of the law (January 1998) showed poor understanding of SHS and the new law among stand alone bars respondents. However, positive changes can be observed among both types of bars, with greater changes among stand alone bars in the 2002 survey. Bivariate associations were confirmed in the multivariate setting, controlling for type of bar, respondent's position in the bar, and smoking status. These findings suggest that the initial negative view of the law has been largely reversed.

Interestingly, given a hypothetical scenario, respondents to the survey in 2002 were more likely to report that they would ask patrons who smoked inside to stop or to go outside, but less likely to say smoking inside was against the law. This

\begin{tabular}{|c|c|c|c|}
\hline & \multirow[b]{2}{*}{ Type of bars } & \multirow{2}{*}{$\frac{1998(n=651)}{\%(S E)}$} & \multirow{2}{*}{$\begin{array}{l}2002(n=650) \\
\%(S E)\end{array}$} \\
\hline & & & \\
\hline Do you prefer working in a smoke-free environment? & $\begin{array}{l}\text { Stand alone bar } \\
\text { Combination bar }\end{array}$ & $\begin{array}{l}17.3(1.9) \\
52.3(3.1)\end{array}$ & $\begin{array}{l}50.9(4.7)^{* * *} \\
79.6(1.7)^{* * *}\end{array}$ \\
\hline $\begin{array}{l}\text { How concerned are you about the effects of } \\
\text { secondhand smoke on your health? }\end{array}$ & $\begin{array}{l}\text { Stand alone bar } \\
\text { Combination bar }\end{array}$ & $\begin{array}{l}21.6(2.1) \\
54.7(3.1)\end{array}$ & $\begin{array}{l}45.5(4.7)^{* * *} \\
61.5(2.1)\end{array}$ \\
\hline $\begin{array}{l}\text { How important is it to have a smoke-free } \\
\text { environment inside your bar? }\end{array}$ & $\begin{array}{l}\text { Stand alone bar } \\
\text { Combination bar }\end{array}$ & $\begin{array}{l}20.9(2.1) \\
58.1(3.1)\end{array}$ & $\begin{array}{l}57.1(4.7)^{\star * \star} \\
80.5(1.7)^{\star * \star}\end{array}$ \\
\hline \multicolumn{4}{|l|}{$\begin{array}{l}\text { If someone came into your bar and began to smoke, } \\
\text { what would you or the bar staff typically do?f }\end{array}$} \\
\hline Ask them to stop/go outside & $\begin{array}{l}\text { Stand alone bar } \\
\text { Combination bar }\end{array}$ & $\begin{array}{l}43.0(2.5) \\
75.2(2.7)\end{array}$ & $\begin{array}{l}82.1(3.6)^{\star * \star} \\
86.8(1.5)^{\star * \star}\end{array}$ \\
\hline Tell them it's against the law & $\begin{array}{l}\text { Stand alone bar } \\
\text { Combination bar }\end{array}$ & $\begin{array}{l}62.9(2.4) \\
42.6(3.1)\end{array}$ & $\begin{array}{l}33.0(4.5)^{* * *} \\
34.6(2.1)^{*}\end{array}$ \\
\hline Is complying with the law easy? $\ddagger, \S$ & $\begin{array}{l}\text { Stand alone bar } \\
\text { Combination bar }\end{array}$ & & $\begin{array}{l}53.6(4.7) \\
88.0(1.7)\end{array}$ \\
\hline $\begin{array}{l}\text { Do you think the law protects your health and/ } \\
\text { or the health of other bar employees?§ }\end{array}$ & $\begin{array}{l}\text { Stand alone bar } \\
\text { Combination bar }\end{array}$ & & $\begin{array}{l}65.2(4.5) \\
86.8(1.5)\end{array}$ \\
\hline \multicolumn{4}{|c|}{$\begin{array}{l}\text { †To simplify the analysis, we combined "very concerned" and "somewhat concerned" as "concerned", "not too } \\
\text { concerned" and "not at all concerned" as "not concerned". Similarly, "very important" and "somewhat } \\
\text { important" were combined. } \\
\text { †Multiple choices were allowed. } \\
\text { §Questions were only asked in the } 2002 \text { survey. } \\
\text { " } p<0.05 ;{ }^{* *} p<0.01 ; \text {; }{ }^{* * *} p<0.001\end{array}$} \\
\hline
\end{tabular}




\section{What this paper adds}

Worldwide, more and more governments are pursuing secondhand smoke (SHS) workplace protection policy that encompasses bars, but little is known of the public acceptance of the law, especially among key stakeholders such as bar owners and employees.

This study showed that a positive and significant attitudinal change occurred among California's bar owners, managers and bartenders regarding SHS and the smoke-free bar in a four-and-a-half-year span. The results suggested that a statelevel smoke-free bar law is feasible to implement.

difference indicates that, based on their self report, bar employees were more willing to take action to achieve compliance with the law instead of just telling patrons that smoking in the bar was against the law. It suggests a better understanding, acceptance, and desire to comply with the law.

Our results show that the smoke-free bar law in California is increasingly popular, even among bar owners and employees. The implication from this study is that an ambitious state level public health policy on SHS control is feasible to implement. ${ }^{1823}$

\section{ACKNOWLEDGEMENTS}

The authors thank Mark DiCamillo and Field Research Corporation for leading the data collection and Matthew Le Veque for assisting immensely in planning and implementing the study. Thanks also to Joanne Wellman-Benson, Paul Hunting, Schaelene Rollins, and Greg Oliva for their assistance in the survey design.

\section{Authors' affiliations}

H Tang, D W Cowling, C M Stevens, J C Lloyd, California Department of Health Services, Sacramento, California, USA

\section{REFERENCES}

1 US Environmental Protection Agency. Respiratory health effects of passive smoking: lung cancer and other disorders. Washington, DC: US Environmental Protection Agency, Office of Air and Radiation, 1992; EPA/ 600/6-90/006F.
2 Siegel M. Involuntary smoking in the restaurant workplace. A review of employee exposure and health effects. JAMA 1993;270:490-3.

3 Maskarinec MP, Jenkins RA, Counts RW, et al. Determination of exposure to environmental tobacco smoke in restaurant and tavern workers in one US city. $J$ Expo Anal Environ Epidemiol 2000;10:36-49.

4 Al-Delaimy W, Fraser T, Woodward A. Nicotine in hair of bar and restaurant workers. N Z Med J 2001;114:80-3.

5 Dimich-Ward H, Gee H, Braver M, et al. Analysis of nicotine and cotinine in the hair of hospitality workers exposed to environmental tobacco smoke. J Occup Environ Med 1997;39:946-8.

6 Eisner MD, Smith AK, Blanc PD. Bartenders' respiratory health after establishment of smoke-free bars and taverns. JAMA 1998;280:1909-14.

7 American Nonsmokers' Right Foundation. Municipalities with $100 \%$ smokefree bar ordinances. 3 June 2003. http://no-smoke.org/barordlist.pdf Accessed 3 July 2003.

8 California General Assembly. An Act to Add Section 6404.5 to the Labor Code, Relating to Occupational Safety and Health, Sess (1994). Assembly Bill 13.

9 American Beverage Institute. American Beverage Institute Market Research Study. Los Angeles, California: KPMG Peat Marwick, April 1998.

10 National Smokers Alliance. Mom-and-pop tavern owners blast anti-smoking groups' dismissive attitude toward their economic suffering [press release] National Smokers Alliance, 19 February 1998.

11 Romano B. Barkeeps fume over smoking ban: local tavern owners join statewide chorus saying new law is harming their business. San Jose Mercury News 27 February 1998:B2.

12 Tang $\mathrm{H}$, Cowling DW, Lloyd JC, et al. Changes of attitudes and patronage behaviors in response to a smoke-free bar law. Am J Public Health 2003;93:611-17.

13 Glantz SA. Effect of smoke-free bar law on bar revenues in California. Tobacco Control 2000:9:111-12.

14 Cowling DW, Bond P. Bar revenues are not affected by smoke-free laws in California-the last call. (In preparation).

15 Scollo M, Lal A, Hyland A, et al. Review of the quality of studies on the economic effects of smoke-free policies on the hospitality industry. Tobacco Control 2003:12:13-20.

16 California Department of Health Services. A model for change: the California experience in tobacco control. Sacramento, California: California Department of Health Services, Tobacco Control Section, 1998.

17 California Department of Health Services. Eliminating smoking in bars, tavern and gaming clubs: the California Smoke-free Workplace Act. Sacramento, California: California Department of Health Services, Tobacco Control Section, 2001.

18 Kiser D, Boschert T. Eliminating smoking in bars, restaurants, and gaming clubs in California: BREATH, the California Smoke-Free Bar Program. J Public Health Policy $2001 ; 22: 81-7$

19 Steptoe A, Wardle J, Fuller R, et al. Seatbelt use, attitudes, and changes in legislation: an international study. Am J Prev Med 2002;23:254-9.

20 Snortum JR, Berger DE. Drinking-driving compliance in the United States: perceptions and behavior in 1983 and 1986. J Stud Alcohol 1989;50:306-19.

21 Miller C, Wakefield M, Kriven S, et al. Evaluation of smoke-free dining in South Australia: support and compliance among the community and restaurateurs. Aust N Z J Public Health 2002:26:38-44.

22 SAS Institute. SAS/STAT Users Guide, Version 8. Vol 2. Cary, North Carolina: SAS Institute Inc, 1999.

23 Magzamen S, Glantz SA. The new battleground: California's experience with smoke-free bars. Am J Public Health 2001;91:245-52. 